\title{
Isolation and Characterization of Vibrio Species from Shrimp and Artemia Culture and Evaluation of the Potential Virulence Factor
}

\section{Kumaran $\mathrm{T}^{1,2 *}$ and Citarasu $\mathrm{T}^{2}$}

${ }^{1} P G$ and Research Department of Zoology, Muslim Arts College, Thiruvithancode, Kanyakumari District 629174, Tamilnadu, India

${ }^{2}$ Centre for Marine Science and Technology, Manonmaniam sundaranar University, Rajakkamangalam, Kanyakumari District 629502, Tamilnadu, India

\begin{abstract}
The intensive cultivation conditions for marine shellfish larvae may easily cause microbial problems. Vibrio species are commonly present in disease affected shrimp farms, seawater and sediments. Vibriosis has resulted in severe economic losses to aquaculture worldwide and affects many farm-raised fishes, shrimps, crustaceans and Artemia. $V$. harveyi and closely related bacterial species are commonly found in estuarine and coastal marine habitats and can readily be isolated from different environmental sources. The lethal toxicity of extracellular products (ECPs) produced by $V$. harveyi $V$. anguillarum and $V$. parahaemolyticus isolated from shrimp and Artemia culture. Also the virulence factors such as protease, proteolytic activity, and phospholipase and lipase activity and haemolytic activity was studied the virulence strains compared with the non-virulent Vibrio strains. This paper addresses the virulence and epidemiology of vibrio pathogen; pathogenesis of its disease.
\end{abstract}

Keywords: V. harveyi; Artemia; Economic losses; Extracellular products; Virulence

\section{Introduction}

Indian aquaculture advanced from a traditional practice and developed into an important food production sector, contributing to national economies and providing better livelihoods for rural and farming families. Increasing world trade liberalization and globalization as well as improved transportation efficiency contributed to a great extent for the farmer to be part of a production chain for the delivery of the safe and high quality products to the end users. The aquaculture sector has become a key supplier of aquatic food, provider of direct and indirect employment, and a great source of foreign trade earnings. However, the higher growth of shrimp farming operations has become a potential cause of many problems. Over exploitation of brood stock fishes is one of the important issues. In addition, the expansion of shrimp culture is accompanied by local environmental degradation and the occurrence of diseases of both infectious and noninfectious etiologies [1].

Disease has become a severe constraint to aquaculture leading to subsequent increase in the cost of production year by year. Frequent occurrence of diseases is the major cause of insufficient reduction in aquaculture. In fact, vibriosis is a major disease problem in shrimp aquaculture, causing high mortality and severe economic loss in all producing countries. The major species causing vibriosis in shrimp are Vibrio alginolyticus, V. anguillarum, V. harveyi, and V. parahaemolyticus [2]. Vibrio infections can spread rapidly when fish are confined in heavily stocked, commercial systems and morbidity may reach $100 \%$ in affected facilities.

Vibrio species are very common in marine and estuarine habitats and on the surface and in the intestinal contents of marine animals [3]. Lavilla-Pitogo [4] has reported eight bacterial genera that have been associated with the diseases in penaeid culture systems. Only two groups occur quite commonly: filamentous bacteria and Vibrios, with the latter being more important. Many Vibrio species have been reported in penaeids: V. alginolyticus, $V$. anguillarum, V. cholerae (non-01), $V$. damsela, V. fluvialis, V. nereis, V.splendidus, V. tubiashii, V. vulnificus, $V$. parahaemolyticus and $V$. harveyii [4]. Among the several species of vibrios, $V$. harveyi, V. penaecida, V.parahaemolyticus and $V$. vulnificus [4-6] are the most important pathogens in shrimp. Artemia, a nauplii, however, are also considered a possible vector for the introduction of viruses and bacteria into rearing systems and it has been speculated that Artemia can act as a reservoir or carrier for bacterial pathogens such as Vibrio, Erwinia, Micrococcus, Staphylococcus and Bacillus [7-10]. Vibrios are important bacterial pathogens for animals reared in aquaculture [11-13] and several virulence factors involved in the potential pathogenic capacity of Vibrio species. Some strains of Vibrio secrete haemolysins and cytotoxins and were also strong exotoxin producers in some Vibrio strains, iron - acquisition systems play on essential role in their pathogenicity [14].

However, the virulence factors of $V$. harveyi are not completely understood [15]. Considered that proteases, phospholipase, haemolysins or exotoxins might be important for pathogenicity [16]. Considered that cysteine protease was the major exotoxin. It has been reported that the biological activities in the ECP may contribute to the development of disease in terms of enhancing bacterial nutrition or as aggressins enabling the bacteria to counteract the host defence systems [17]. In this study, live cells and ECPs from a wide range of $V$. harveyi isolates were examined for pathogenicity, shrimp and Artemia culture, and identification of putative virulence mechanisms.

\section{Materials and Methods}

\section{Source of bacterial cultures}

Three pathogenic Vibrio strains were selected for this study from a variety of sources. V. harveyi, V. anguillarum and V. parahaemolyticus were isolated from infected Artemia franciscana culture tank at CMST campus. And they were isolated from infected semi-intensive

*Corresponding author: Kumaran T, Assistant professor, PG and Research Department of Zoology, Muslim Arts College, Thiruvithancode, Kanyakumari District 629174, Tamilnadu, India; Tel: +919715606022; E-mail: kumaranmac@gmail.com

Received May 25, 2016; Accepted June 20, 2016; Published June 28, 2016

Citation: Kumaran T, Citarasu T (2016) Isolation and Characterization of Vibrio Species from Shrimp and Artemia Culture and Evaluation of the Potential Virulence Factor. Intel Prop Rights. 4: 153. doi:10.4172/2375-4516.1000153

Copyright: (c) 2016 Kumaran T, et al. This is an open-access article distributed under the terms of the Creative Commons Attribution License, which permits unrestricted use, distribution, and reproduction in any medium, provided the original author and source are credited. 
shrimp farms at Marakkanam, Kancheepuram district of Tamilnadu. The collected shrimp and Artemia samples were kept in icebox and transported to the laboratory and stored at $-20^{\circ} \mathrm{C}$. The infected samples were washed 3 times with $100 \mathrm{ml}$ of sterile sea water on sterile filters. It was homogenized in a sterile glass homogenizer with sterile water and the samples were serially diluted up to 10 fold. One hundred micro liters of these samples were plated on TCBS agar medium. All the plates were incubated between 28 and $30^{\circ} \mathrm{C}$. After 2 to 7 days, colonies growth was observed and was selected based their morphological appearance, physiological and biochemical confirmations as well as based on the characteristics described in Bergey's Manual of Systematic Bacteriology [18].

\section{Bacteria and extracellular products (ECP)}

Stock cultures of Vibrio harveyi, V.parahaemolyticus V.anguillarum strain were grown on tryptic soy agar (TSA; supplemented with $1 \%$ $\mathrm{NaCl}$ ) for $24 \mathrm{~h}$ at $25^{\circ} \mathrm{C}$. Two swabs of these bacteria suspended in $5 \mathrm{ml}$ phosphate buffered saline (PBS) pH 7.2, were spread onto cellophane overlying TSA $(11 \% \mathrm{NaCl})$ and grown for $24 \mathrm{~h}$ at $25^{\circ} \mathrm{C}$. The ECP was harvested and added $10 \mathrm{ml}$ PBS to the surface of the cellophane overlying TSA $(11 \% \mathrm{NaCl})$ and spread completely. The harvested bacterial suspension was then centrifuged at $25,000 \mathrm{~g}$ for $60 \mathrm{~min}$ at $4^{\circ} \mathrm{C}$; the pellet was discarded. The supernatant fluids were passed through a $0.22-\mu \mathrm{m}$ filter, and the ECP was stored in $1-\mathrm{ml}$ aliquots at $4^{\circ} \mathrm{C}$. Total protein was measured by the method of Bradford with bovine serum albumin as standard.

\section{Enzyme activities of bacteria and ECP}

Caseinase, gelatinase and phospholipase activities of ECP were detected by placing $25 \mathrm{ml}$ of sample in wells cut in agarose $1 \%$ in PBS, $\mathrm{pH} 7.2$ that contained either $1 \%$ casein, $1 \%$ gelatin, $0.2 \%$ starch, $2.5 \%$ egg yolk, $1 \%$, respectively. After incubation at $28^{\circ} \mathrm{C}$ for $24 \mathrm{~h}$, the diameter of the lytic halo around each well was measured. Similarly, enzyme activities of bacteria were measured by spot inoculating bacteria on agar plates containing the respective substrates as described above. The diameter of the lytic halo around each colony was measured.

\section{Hemolysin test}

Bacterial strains were grown overnight in microbial broth at $25^{\circ} \mathrm{C}$ in incubator and the initial $\mathrm{OD}_{550}$ was measured using (UVSpectrophotometer). A separate falcon tube was taken and about 200 $\mu \mathrm{l}$ of sheep blood was added and well mixed in $20 \mathrm{ml}$ of autoclaved Marine agar. The mixture is then poured on a plate and left $15 \mathrm{~min}$ for drying avoiding any air bubbles. Three different drops of $10 \mu$ diluted bacterial solution is then spotted on the plate. Finally, the plates were covered with parafilm and kept in incubator at $28^{\circ} \mathrm{C}$ for $48 \mathrm{hrs}$. After incubation, hemolytic zones were observed. The test was repeated two times.

\section{Proteolytic assay}

The enzyme casein dissolved at $1 \%$ in $0.1 \mathrm{~mol} / \mathrm{lt}$ of Glycine sodium hydroxide buffer(p $\mathrm{H} \mathrm{9.6)}$. To that $1 \mathrm{ml}$ of extra cellular protein to 1 $\mathrm{ml}$ of the above solution was added. It was incubated at $30^{\circ} \mathrm{C}$ for 10 minutes. The reaction was stopped by adding $0.1 \mathrm{~mol}$ of $1 \mathrm{~mol} / \mathrm{lit}$ of Trichloro acetic acid. Then it was centrifuged at $6000 \mathrm{rpm}$ for 10 minutes. Finally the supernatant was collected and the optical density was measured at $380 \mathrm{~nm}$. Tri chloro acetic acid was used as control [19].

\section{In vivo virulence studies}

The bacteria were grown in TSB medium at $28^{\circ} \mathrm{C}$ for 18 hours. The cells were centrifuged at $5000 \mathrm{rpm}$ for 10 minutes. The pellets were washed with sterile saline $(0.85 \%(\mathrm{~W} / \mathrm{V}) \mathrm{NaCl})$ by centrifuging at 5000 rpm for 10 minutes. Pellet was collected and mixed with Phosphate Buffered Saline (PBS pH 7.4) challenged with different stages (nauplii, and adult) of Artemia species A. franciscana at the rate of more than $10^{7} \mathrm{Cfu} / \mathrm{ml}$ in the culture tank. The overall survival rate after challenge were assessed every 24 hours interval of the culture period. The protocol of total Vibrio count (TVC) of the wild collected A. franciscana, the samples were homogenized, serially diluted, toxicity inhibition tests was described as spread onto Petri dish containing the TCBS agar. The plates were incubated at $37^{\circ} \mathrm{C}$ for 24 hours. Triplicates were maintained. After incubation the numbers of colonies formed were counted.

\section{Data Analysis}

Data obtained from virulence factors as well as cumulative mortality were analysed using one way ANOVA $(\mathrm{P}<0.05$ as significant level). Means were also compared using SNK test.

\section{Results}

\section{Characterization of bacterial strains}

Three major Vibrio species, such as $V$. harveyi $V$. anguillarum and $V$. parahaemolyticus were isolated from the infected shrimp farms at Marakkanam, Kancheepuram district of Tamilnadu and Artemia franciscana culture tank at CMST campus. These strains were confirmed by morphological and biochemical confirmative tests (Table 1). The infected shrimp showed symptoms such as lethargy, loss of balance, whirling movement and general weakness within $6 \mathrm{~h}$ after challenge with bacteria. Hemolymph failed to clot and slight reddening of pleopods was also noticed. To standardizing the growth, the selected strains were cultured and reached the stationary phase within 2 hours in both the Tryptic soy broth and Nutrient broth.

\section{Characterization of Vibrio ECP}

The total proteins estimated from the extracellular proteins of as $V$. harveyi $V$. anguillarum and $V$. parahaemolyticus were given in the Table 1. The maximum protein content was observed in the Vibrio harveyi (101.72 U/ml). The moderate value was observed from $V$. anguillarum and $V$. parahaemolyticus $(94.48,94.49 \mathrm{U} / \mathrm{ml}$ respectively). The ECP of the strain $V$. harveyi $V$. anguillarum and $V$. parahaemolyticus were harvested after $24 \mathrm{~h}$ of incubation of the culture at $25^{\circ} \mathrm{C}$. The virulence factors were tested in different enzymatic activities such as extracellular protein preparation. caseinase, gelatinase and phospholipase activity (Table 2).

\section{Haemolytic activity}

The haemolytic activity of $V$. harveyi $V$. anguillarum and $V$.

\begin{tabular}{|c|c|c|c|c|}
\hline S. no & $\begin{array}{c}\text { Concentration } \\
(\boldsymbol{\mu l})\end{array}$ & \multicolumn{3}{|c|}{ ECP Samples } \\
\cline { 3 - 5 } & 10 & $5.76 \pm 0.08$ & $10.56 \pm 0.08$ & $3.88 \pm 0.089$ \\
\hline 1 & 20 & $16.36 \pm 0.12$ & $21.30 \pm 0.01$ & $8.28 \pm 0.24$ \\
\hline 2 & 30 & $25.50 \pm 0.08$ & $31.89 \pm 0.04$ & $21.10 \pm 0.12$ \\
\hline 3 & 40 & $35.10 \pm 0.47$ & $41.62 \pm 0.02$ & $33.32 \pm 0.08$ \\
\hline 4 & 50 & $49.30 \pm 0.06$ & $52.54 \pm 0.05$ & $45.06 \pm 0.03$ \\
\hline 5 & 60 & $57.46 \pm 0.09$ & $61.16 \pm 0.01$ & $55.82 \pm 0.08$ \\
\hline 6 & 70 & $66.95 \pm 0.04$ & $71.08 \pm 0.08$ & $66.70 \pm 0.08$ \\
\hline 7 & 80 & $76.53 \pm 0.01$ & $81.88 \pm 0.01$ & $76.82 \pm 0.08$ \\
\hline 8 & 90 & $85.68 \pm 0.08$ & $92.05 \pm 0.01$ & $86.12 \pm 0.08$ \\
\hline 9 & 100 & $94.48 \pm 0.08$ & $101.72 \pm 0.03$ & $95.33 \pm 0.09$ \\
\hline 10 & & & & \\
\hline
\end{tabular}

Table 1: Total protein estimation $(\mu \mathrm{g})$ of the ECP of pathogenic Vibrio sp by Bradford's assay. 
Citation: Kumaran T, Citarasu T (2016) Isolation and Characterization of Vibrio Species from Shrimp and Artemia Culture and Evaluation of the Potential Virulence Factor. Intel Prop Rights. 4: 153. doi:10.4172/2375-4516.1000153

Page 3 of 5

\begin{tabular}{|c|c|c|c|c|c|c|c|c|c|c|}
\hline \multirow[t]{3}{*}{ S. no } & \multirow[t]{3}{*}{ Strain } & \multicolumn{9}{|c|}{ Enzyme activities } \\
\hline & & \multicolumn{3}{|c|}{ Caseinase } & \multicolumn{3}{|c|}{ Gelatinase } & \multicolumn{3}{|c|}{ Phospholipase } \\
\hline & & C. zone (mm) & C. $\mathrm{dm}(\mathrm{mm})$ & Ratio & C. zone (mm) & C. $\mathrm{dm}(\mathrm{mm})$ & Ratio & C. zone (mm) & C. $\mathrm{dm}(\mathrm{mm})$ & Ratio \\
\hline 1 & V. harveyi & $16.5 \pm 1.0$ & $15.5 \pm 1.0$ & $1.1 \pm 0.0$ & $16.5 \pm 1.0$ & $15.5 \pm 1.0$ & $1.1 \pm 0.0$ & $16.5 \pm 1.0$ & $15.5 \pm 1.0$ & $1.1 \pm 0.0$ \\
\hline 2 & V. anguillarum & $13.2 \pm 1.0$ & $7.7 \pm 0.2$ & $1.7 \pm 0.2$ & $13.2 \pm 1.0$ & $7.7 \pm 0.2$ & $1.7 \pm 0.2$ & $13.2 \pm 1.0$ & $7.7 \pm 0.2$ & $1.7 \pm 0.2$ \\
\hline 3 & V. parahaemolyticus & $17.3 \pm 0.5$ & $9.8 \pm 1.2$ & $1.8 \pm 0.5$ & $17.3 \pm 0.5$ & $9.8 \pm 1.2$ & $1.8 \pm 0.5$ & $17.3 \pm 0.5$ & $9.8 \pm 1.2$ & $1.8 \pm 0.5$ \\
\hline
\end{tabular}

Clearing zone $(\mathrm{mm})$ - C. zone, Colony diameter $(\mathrm{mm})$ - C. $\mathrm{dm}$.

Table 2: Enzyme activities towards skim milk powder of pathogenic Vibrio strains.

\begin{tabular}{|c|c|c|c|c|c|c|c|}
\hline \multirow[t]{2}{*}{ S. no } & \multirow[t]{2}{*}{ Strain } & \multicolumn{6}{|c|}{ Incubation time (hour) } \\
\hline & & 18 & 24 & 36 & 48 & 60 & 72 \\
\hline 1 & V. harveyi & $1568.14 \pm 0.04$ & $1795.32 \pm 0.02$ & $2864.01 \pm 0.09$ & $2019.18 \pm 0.05$ & $2061.05 \pm 0.01$ & $1645.82 \pm 0.02$ \\
\hline 2 & V. anguillarum & $1415.18 \pm 0.02$ & $1681.93 \pm 0.01$ & $2316.05 \pm 0.02$ & $1946.46 \pm 0.01$ & $2012.49 \pm 0.06$ & $1418.34 \pm 0.05$ \\
\hline 3 & V. parahaemolyticus & 1256. $41 \pm 0.07$ & $1465.64 \pm 0.01$ & $2156.14 \pm 0.06$ & $1785.54 \pm 0.4$ & $1921.71 \pm 0.01$ & $1258.26 \pm 0.01$ \\
\hline
\end{tabular}

Table 3: Protease assay for pathogenic Vibrio sp isolated from infected shrimp and Artemia species.

parahaemolyticus was tested on the Blood agar plates containing $2 \%$ human blood. The isolates were varied in their ability to lyses the RBC's of human blood. According to the results, $V$. harveyi showed higher haemolytic activity than the $V$. anguillarum and $V$. parahaemolyticus, Figure 1 shows the results of isolates.

\section{Protease assay}

The protease assay and production $(\mathrm{U} / \mathrm{ml})$ of Vibrio species such as $V$. harveyi $V$. anguillarum and $V$. parahaemolyticus were given in the Table 3. The protease is responsible for prawns lost balance and showed whirling movement before succumbing to death. The heatinactivated protease fractions did not cause any mortality. The lowest protease value $1256.41 \mathrm{U} / \mathrm{ml}$ was observed in the $V$. parahaemolyticus and higher protease value was observed in $V$. harveyi $(2864.01 \mathrm{U} / \mathrm{ml})$. In the case of $V$. anguillarum the moderate value was observed (1681.93 $\mathrm{U} / \mathrm{ml}$ ) in 24 hours incubation.

Survival of A. Franciscana nauplii, adult Challenged Vibrio strains at different time intervals

In A. franciscana, the control of nauplii groups survived $91 \%$ when no pathogenic inoculation was given. The survival was observed was 36,39 and $44 \%$ in $V$. anguillarum, $V$. harveyi and $V$. pelagius respectively (Figure 2). In $A$. franciscana, the control of adults groups survived $89 \%$ when no pathogenic inoculation was given. The survival was observed was 28, 19 and $44 \%$ in $V$. anguillarum, $V$. harveyi and $V$. parahaemolyticus respectively (Figure 3 ).

\section{Total Vibrio count after Challenging in A. fransciscana}

The total plate count of different stages was given in the Table 4. In nauplii stage, the lowest load $1.7 \times 10^{7} \pm 2.05 \times 10^{3}$ in the $V$. anguillarum, and the highest load was $1.8 \times 10^{7} \pm 4.08 \times 10^{3}$ in the $V$. parahaemolyticus. In adult stage, the lowest load $2.1 \times 10^{7} \pm 3.68 \times 10^{3}$ in the Vibrio harveyi, and the highest load was $2.5 \times 10^{7} \pm 1.63 \times 10^{3}$ in the V. parahaemolyticus.

\section{Discussion}

Disease problem in aquaculture are currently an important constraint to growth of aquaculture, which has impacted both socioeconomic development and rural livelihoods in some countries [20]. Some Vibrio species are pathogens of fish, eels and frogs as well other vertebrates and invertebrates [21] and can cause Vibriosis, a serious infectious disease in both wild and cultured fish and shellfish [22].The disease can cause significant mortality $(>50 \%)$ in fish culture facilities

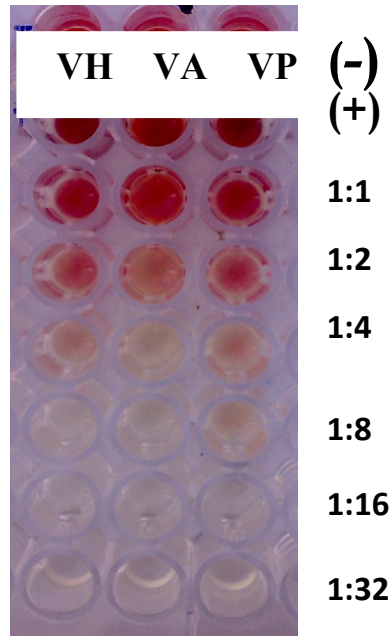

VH: Vibrio harveyi, VA: Vibrio anguillarum, VP: Vibrio parahaemolyticus Figure 1: Haemagglutination activity of the $V$. harveyi, V. anguillarum and $\checkmark$ parahaemolyticus on the micro well titre plate.

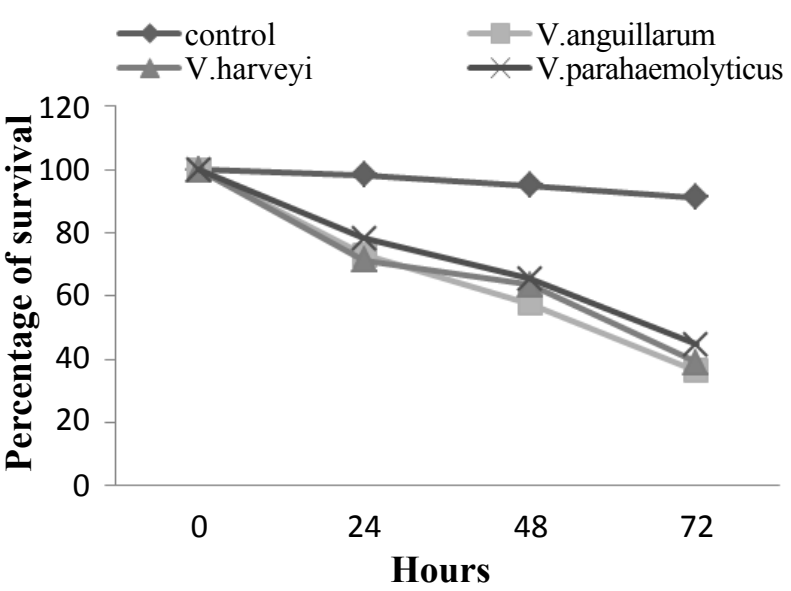

Figure 2: Survival of $A$. franciscana nauplii challenged Vibrio strains at different time intervals.

once as outbreak is in progress. The species associated with disease in fish and shell fish include V. anguillarum (isolated most commonly from 


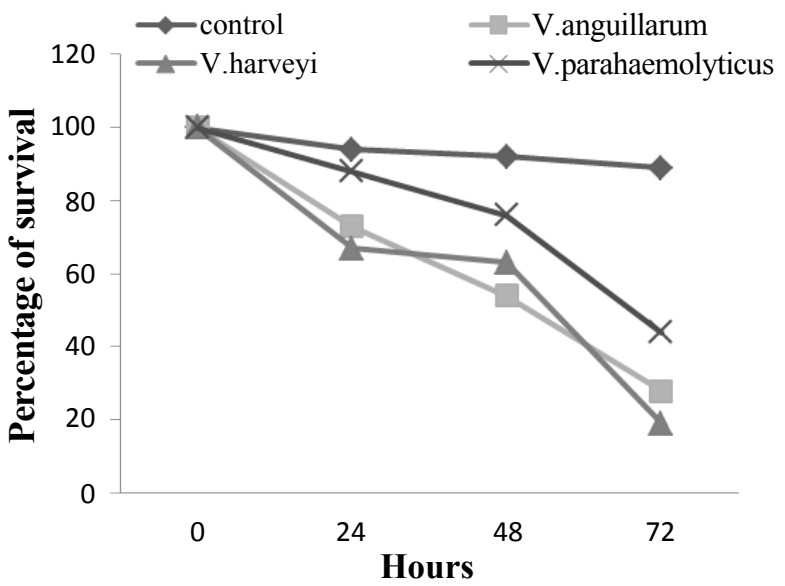

Figure 3: Survival of $A$. franciscana adult challenged Vibrio strains at different time intervals.

\begin{tabular}{|c|c|c|c|}
\hline \multirow{2}{*}{ S.no } & Strains & \multicolumn{2}{|c|}{ Total Vibrio count (Cfu/g) } \\
\cline { 3 - 4 } & & A. franciscana nauplii & A. franciscana adult \\
\hline 1 & V. harveyi & $2.33 \times 10^{3} \pm 1.0 \times 10^{1}$ & $2.1 \times 10^{7} \pm 3.68 \times 10^{3}$ \\
\hline 2 & V. anguillarum & $1.7 \times 10^{7} \pm 2.05 \times 10^{3}$ & $1.8 \times 10^{7} \pm 4.08 \times 10^{3}$ \\
\hline 3 & V. parahaemolyticus & $1.75 \times 10^{3} \pm 0.5 \times 10^{1}$ & $2.5 \times 10^{7} \pm 1.63 \times 10^{3}$ \\
\hline
\end{tabular}

Table 4: Total bacterial count and Total Vibrio count (cfu/g) of the $A$. fransciscana.

marine and brackish water shellfish) V. harveyi, V. alginolyticus and $V$. parahaemolyticus have infected in juveniles and adults [23]. Usually most of the studies have focused on the isolation, characterization and identification of the bacterial strains present in tissues and cultural water at the time of infection. However, pathogenesis studies on this vibrio species originally isolated from Artemia franciscana and Tiger prawn (Penaeus monodon) in the animals have not been previously described. Therefore, a pathogenic Vibrio strain's isolated from diseased prawn and Artemia was used to investigate its extracellular virulence factor(s) in this study.

Our finding suggests that, there is diversification of result concerning the effect of extracellular products on virulence factor production of Vibrio harveyi. Previous report showed that, $V$. harveyi are able to generate various virulence factors i.e. extracellular products (ECP's) responsible for pathogenesis [24,25]. However, in case of $V$. harveyi proteases, phospholipase, hemolysins and cytotoxins are considered as major pathogenicity determinants [24].

Artemia is one of the most important live feed organisms used in the shrimp industry. The importance of brine shrimp was realized as early as 1930, when the high value of its nauplii was described as an ideal food for the larvae of crustaceans in aquaculture. The dry cysts of Artemia can be surface sterilized and the nauplii which hatch out are bacteria free. After this stage, pre adult and adult stage is hatched out. This allows experiments with Vibrio to be performed without the interference of any other bacteria [26]. The ability to simplify the interactions between bacteria and Artemia in this way was considered important and useful for the study of pathology in this very important crustacean.

Proteases present in the ECP of bacteria have been implicated as virulence determinants in fish diseases [27] and in shrimp vibriosis [28]. The bacteria, as well as its ECP, showed high protease activity. Extracellular products secreted by the bacteria were found to be highly toxic to tiger prawn. Similar findings have been reported for $V$. alginolyticus [28]. Also, protease fractions to be highly toxic to tiger prawns. This is the first report of the toxicity of the extracellular protease of $V$. parahaemolyticus to tiger prawn. This finding points to the possible role of proteases as virulence determinants of the bacteria. The results obtained from the present study showed that the pathogenic and virulence characteristics of $V$. anguillarum, $V$. harveyi and $V$. parahaemolyticus are associated with growth standardization, the range of different exotoxins (Haemolysin), and exoenzymes (Protease and lipase). Consistent with the result of caseinase and glelatinase obtained in this study, positive regulation of protease has also been reported before for the $V$. harveyi e.g., vhp metalloprotease gene [29].

The high variability in the chemical composition of ECP from different isolates, suggested intraspecific heterogeneity in the taxon, as has been reported for other fish pathogens [11]. Certainly, the proteolytic activity was variable among the isolates, and there was not any correlation with the total protein content. Overall, the ECP displayed fewer enzymic activities than live cells, suggesting that many of these activities were associated with the cell envelop. Alternatively, it is conceivable that some substrates were internalized. It remains for further study to determine the relationship, if any, between cellassociated and diffusible water soluble pathogenicity factors of $V$. harveyi. Also, the relevance of laboratory-produced ECP preparations to natural infections needs to be addressed. Further studies will also need to evaluate different methods for the detection and quantification of culturable and non-culturable Vibrio spp. pathogenesis at molecular level.

\section{References}

1. Lightner DV, Redman RM (1992) Penaeid virus diseases of the shrimp culture industry of the Americas. In: Fast AW, Lester LJ (eds.) Marine shrimp culture: Principles and Practices, Elsevier, Amsterdam 569-588.

2. Goarant C, Merien F, Berthe F, Mermoud I, Perolat P (1999) Arbitrarily primed PCR to type Vibrio spp pathogenic for Shrimp. Applied and Environmental Microbiology 65: 1145-1151.

3. Kumaran T, Citarasu T (2016) Isolation and Characterization of Virulencerelated properties of pathogenic Vibrio parahaemolyticus isolated from aquatic environments, Mesopotamia. Environmental Journal 2: 57-65.

4. Lavilla-Pitogo CR (1995) Bacterial diseases of Penaeid shrimps: an Asian view. In: Shariff M, Arthur JR, Subasinghe RP (eds.) Diseases in Asian Aquaculture II, Fish Health Section, Asian Fisheries Society, Manila 107-121.

5. Lightner DV (1996) A handbook of shrimp pathology and diagnostic procedures for diseases of penaeid shrimp World Aquaculture Soc, Baton Rouge, Louisiana, USA: 305

6. Ishimaru K, Akagawa-Matsushita M, Muroga K (1995) Vibrio penaeicida sp Nov, a pathogen of kuruma prawns (Penaeus japonicus) Int J Syst Bacteriol 45: $134-138$

7. Austin B, Allen DA (1982) Microbiology of laboratory hatched brine shrimp (Artemia) Aquaculture 26: 369-383.

8. Tatani M, Muroga K, Sugiyama T, Hiramoto Y (1985) Detection of Vibrio anguillarum from reared fry and fingerlings of ayu. Suisan Zoshoku 33: 59-66.

9. Muroga K, Higashi M, Keitiku H (1989) The isolation of intestinal microflora of farmed red seabream Pagrus major and black seabream Acanthopagrus schlegeli larval juvenile stages. Aquaculture 65: 79-88.

10. Nicolas, JL, Robic E, Ansquer D (1989) Bacterial flora associated with a trophic chain consisting of microalgae, rotifers and turbot larvae: influence of bacteria on larval survival. Aquaculture 83: 237-248.

11. Austin B, Austin DA (1999) Bacterial fish pathogens; disease of farmed wild fish (3rdedn) springer - verlog KG, Berlin, Germany.

12. Bergh O, Nilsen F, Samuelsen OB (2001) Diseases, prophylaxis and treatment of the Atlantic halibut. Hippoglossus hippoglossus; a review Dis Aquat Org 48 57-74. 
Citation: Kumaran T, Citarasu T (2016) Isolation and Characterization of Vibrio Species from Shrimp and Artemia Culture and Evaluation of the Potential Virulence Factor. Intel Prop Rights. 4: 153. doi:10.4172/2375-4516.1000153

Page 5 of 5

13. Lightner DV, Radman RM (1998) Shrimp diseases and current diagnostic methods. Aquaculture;164: 201-220.

14. Antonio L, Manzanares EM, Borrego J (1996) Virulence factors of Vibrio P1, the causative agent of brown ring disease in the Manila clam, Ruditapes philippinarum. Aquat Living Resource 9:125-136.

15. Liu PC, Lee KK, Yii KC, Kou GH, Chen SN (1996) Isolation of Vibrio harveyi from diseased kuruma prawns. Penaeus japonicus Curr Microbiol 33: 129-132.

16. Liu PC, Lee KK, Tu CC, Chen SN (1997) Purification and characterization of a cysteine protease produced by pathogenic luminous Vibrio harveyi. Current Microbiology 35:32-39.

17. Ellis $A E$ (1991) An appraisal of the extracellular toxins of Aeromonas salmonicida ssp salmonicida. Journal of Fish Diseases 14: 265-277.

18. Holt JG, Krieg NR, Sneath PHA, Staley JT, Williams ST (1994) Bergey's manual of determinative bacteriology (9thedn) Williams and Wilkins, Baltimore.

19. Citarasu T, Alfred D, Velmurugan K, Thanga VS, Kumaran V, et al. (2011) Isolation of Aeromonas hydrophila from infected ornamental fish hatchery during massive disease outbreak, International Journal of Current Research 2: $37-41$.

20. FAO (2002) The state of world fisheries and aquaculture, Food and Agriculture. Organisation of the United Nations, Rome, Italy, 150.
21. Todar K (2005) Vibrio cholerae and Asiatic cholera, textbookofbacteriology.net/ cholera.

22. Austin B, Austin DA (1993) Bacterial fish pathogens (2ndedn) Diseases in farmed and wild fish. Ellis Horwood Ltd, Chichester, United Kingdom.

23. Thompson FL, lida T, Swings J (2004) Biodiversity of Vibrios. Microbiol Molecul Biol Rev 68: 403-431.

24. Liu PC, Lee KK, Chen SN (1996) Pathogenicity of different isolates of Vibrio harveyi in tiger prawn, Penaeus monodon. Letters in Applied Microbiology 22: 413-416.

25. Austin B, Zhang XH (2006) Under the microscope Vibrio harveyi: a significant pathogen of marine vertebrates and invertebrates. LettAppl Microbiol 43: 119-124.

26. Lightner DV (1977) Vibrio disease in shrimps. In: Disease diagnosis and contro in North American marine Aquaculture 19-26.

27. Kanemori Y, Nakai T, Muroga K (1987) The role of extracellular protease produced by Vibrio anguillarum Fish Pathol 22: 153-158.

28. Lee KK, Liu PC, Kou GH, Chen SN (1997) Passive immunization of tiger prawn Penaeus mondon using rabbit antisera to Vibrio Harvey.i Letters in Applied Microbilogy 25: 34-37.

29. Mok KC, Wingreen NS, Bassler BL (2003) Vibrio harveyi quorum sensing: a coincidence detector for two autoinducers controls gene expression. EMBO J 22: $870-881$. 